\title{
Switching to Online Medical Education: The Minority Perspective [Letter]
}

\section{Mariyah Bashir}

Faculty of Medicine and Health, University of Leeds, Leeds, LS2 9JT, UK

\section{Dear editor}

I recently read the qualitative study by Wang et al on the student and teacher perspective on the transition to online medical education in China as a result of the COVID-19 pandemic. ${ }^{1}$ As a final year medical student who experienced much of my fourth-year medical degree and intercalated master's degree teaching online, I felt compelled to offer insight into some of the recommendations highlighted in the paper.

Much like the authors suggest, the shift from face-to-face to online teaching was abrupt not only in China, but also in the UK. A survey conducted across 39 out of 40 UK medical schools found that within the first five weeks of the UK lockdown, medical education teaching had shifted online. ${ }^{2}$ As the authors discuss, students found online medical education satisfying with clear arrangements, objectives and learning resource provision. ${ }^{1}$ In comparison, UK medical students did not necessarily enjoy online teaching, but appreciated the time and money saved, as well flexibility, of online learning. ${ }^{2}$ Given the level of disruption to education caused by the COVID-19 pandemic, and the negative impacts expected to persist for months, and if not years to come, there is a need to address the mid-term and longterm measures which are required to be put in place in order to minimise disruption to learning for medical students. ${ }^{3}$ Examples of important measures highlighted in the study include the need for sufficient infrastructure which can adequately support the technological needs of students, as well as adequate staff training. ${ }^{1}$

Whilst the article offered extensive insight into the measures which are required if online medical teaching is to be successfully delivered, it failed to mention the specific needs of students from varying diverse groups or suggest that these are even necessary to consider. Examples of such groups include those from under-represented socio-economic backgrounds and ethnic minorities. This current letter serves to highlight the specific considerations of ethnic minority students when considering the delivery of online medical education. In the current sociopolitical climate, it is vital that medical schools acknowledge the potentially disproportionate impact that online medical education could have on the experiences and learning of Black, Asian and Minority Ethnic (BAME) medical students. As most institutions are already aware, there exists an awarding gap in higher education, whereby BAME medical students and professionals underachieve in comparison to their White colleagues. ${ }^{4}$ Countless studies have highlighted the need for social interaction in the transfer of academic knowledge, and 
how ethnicity impacts and potentially limits the sharing of information, which subsequently affects academic performance. $^{5}$ This segregation is at risk of being exacerbated for BAME students, as students can find online teaching isolating, with little interaction from peer-to-peer as well as with teachers and educators. ${ }^{1,2}$ Therefore, as a BAME medical student who has lived experiences of the impacts of social segregation on academic learning, it is vital that medical institutions, globally as well as in the UK, consider the specific needs of ethnic minority students when planning and delivering medical content online. I highly encourage collaborative and honest dialogue between ethnic minority students and faculties with the appropriate packages of support, alongside the creation of safe and supportive spaces whereby students can raise concerns in order to minimise the potential for this virus to exacerbate the pedagogy of structural inequalities which already exist in medical education.

\section{Disclosure}

The author reports no conflicts of interest in this communication.

\section{References}

1. Wang Y, Yu R, Liu Y, et al. Students' and teachers' perspective on the implementation of online medical education in China: a Qualitative Study. Adv Med Educ Pract. 2021;12:895-903. doi:10.2147/AMEP. S323397

2. Dost S, Hossain A, Shehab M, et al. Perceptions of medical students towards online teaching during the COVID-19 pandemic: a national cross-sectional survey of $2721 \mathrm{UK}$ medical students. BMJ Open. 2020;10(11):1-10. doi:10.1136/bmjopen-2020-042378

3. Al-Samaraee A. The impact of the COVID-19 pandemic on medical education: a student perspective. Br J Hosp Med. 2020;81(9):19-22. doi:10.12968/hmed/2020.0523

4. Claridge H, Stone K, Ussher M. The ethnicity attainment gap among medical and biomedical science students: a qualitative study. $B M C$ Med Educ. 2018;18(1):1-12. doi:10.1186/s12909-018-1426-5

5. Woolf K, Potts HWW, Patel S, et al. The hidden medical school: a longitudinal study of how social networks form, and how they relate to academic performance. Med Teach. 2012;34(7):577-586. doi:10.3109/0142159X.2012.669082

Dove Medical Press encourages responsible, free and frank academic debate. The content of the Advances in Medical Education and Practice 'letters to the editor' section does not necessarily represent the views of Dove Medical Press, its officers, agents, employees, related entities or the Advances in Medical Education and Practice editors. While all reasonable steps have been taken to confirm the content of each letter, Dove Medical Press accepts no liability in respect of the content of any letter, nor is it responsible for the content and accuracy of any letter to the editor.

\section{Publish your work in this journal}

Advances in Medical Education and Practice is an international, peerreviewed, open access journal that aims to present and publish research on Medical Education covering medical, dental, nursing and allied health care professional education. The journal covers undergraduate education, postgraduate training and continuing medical education including emerging trends and innovative models linking education, research, and health care services. The manuscript management system is completely online and includes a very quick and fair peer-review system. Visit http://www.dovepress.com/testimonials.php to read real quotes from published authors. 